\title{
Paying for costly pharmaceuticals: regulation of new drugs in Australia, England and New Zealand
}

\author{
James P Raftery
}

T he rising cost of pharmaceuticals has prompted concern globally, leading various countries to institute arrangements to control public coverage and costs generally. ${ }^{1}$ Among the longest established schemes are those in Australia, existing since 1987, 2,3 and in New Zealand, since 1993. The United Kingdom established the National Institute for Health and Clinical Excellence (NICE) in 1999.

Although the processes used in these countries have been described, ${ }^{4-6}$ their decisions on whether to fund drugs with low cost-effectiveness have not been formally compared.

\section{Pharmaceutical funding criteria in the UK, Australia and NZ}

The UK, Australia and NZ are similar, not only in terms of economic development, but also in terms of health and spending on pharmaceuticals. All spend around 1\% of gross domestic product on pharmaceuticals. ${ }^{1}$ Each appraises new drugs: through NICE in the UK, the Pharmaceutical Benefits Advisory Committee (PBAC) in Australia, and the Pharmaceutical Management Agency (PHARMAC) in NZ. Although all new drugs are appraised in Australia and NZ, NICE reviews only around 20 per year referred to it by the government. Appraisal criteria vary among the three countries, as shown in Box $1{ }^{7-9}$ but all include clinical effectiveness and cost-effectiveness. Each authority has broadly similar guidelines for economic assessment. ${ }^{4}$ Australia also includes the "rule of rescue" in its criteria. ${ }^{10}$

Given that cost-effectiveness is but one of several criteria, authorities have been reluctant to state any threshold level above which drugs are deemed to be unacceptable value for money. However, NICE has stated that when the cost per quality-adjusted life year (QALY) is above $£ 20000$ (about A $\$ 50000$, NZ\$55 000):

1 Criteria used by regulatory agencies for funding new drugs

\begin{tabular}{|c|c|c|}
\hline England $(\mathrm{NICE})^{7}$ & Australia (PBAC) ${ }^{8}$ & New Zealand (PHARMAC) ${ }^{9}$ \\
\hline $\begin{array}{l}\text { - Clinical effectiveness } \\
\text { and cost-effectiveness } \\
\text { (cost/QALY) }\end{array}$ & $\begin{array}{l}\text { - Clinical effectiveness } \\
\text { and cost-effectiveness } \\
\text { (largely cost/QALY) }\end{array}$ & $\begin{array}{l}\text { - Clinical effectiveness and } \\
\text { cost-effectiveness } \\
\text { (cost/QALY) }\end{array}$ \\
\hline - Uncertainty & $\begin{array}{l}\text { - Price of alternative } \\
\text { brands or drugs in } \\
\text { same therapeutic class }\end{array}$ & $\begin{array}{l}\text { - Health needs, including } \\
\text { those of Māori and Pacific } \\
\text { Islander peoples }\end{array}$ \\
\hline $\begin{array}{l}\text { - Nature of health } \\
\text { condition }\end{array}$ & - Budget impact & - Budget impact \\
\hline $\begin{array}{l}\text { - Innovation of } \\
\text { technology }\end{array}$ & $\begin{array}{l}\text { - "Rule of rescue" (where } \\
\text { appropriate) }\end{array}$ & $\begin{array}{l}\text { - Cost-effectiveness of drugs } \\
\text { versus other interventions }\end{array}$ \\
\hline $\begin{array}{l}\text { - Wider costs and } \\
\text { benefits }\end{array}$ & & - Clinical benefits and risk \\
\hline \multirow[t]{2}{*}{ - Precedents } & & - Direct costs to users \\
\hline & & $\begin{array}{l}\text { - Availability of alternative } \\
\text { treatments }\end{array}$ \\
\hline
\end{tabular}

$\mathrm{NICE}=$ National Institute for Health and Clinical Excellence. PBAC $=$ Pharmaceutical Benefits Advisory Committee. PHARMAC = Pharmaceutical Management Agency. QALY= quality-adjusted life year.

\section{ABSTRACT}

- The United Kingdom, Australia and New Zealand use different criteria for public funding of pharmaceuticals, but all include estimates of clinical effectiveness and costeffectiveness.

- Drug appraisal is done through the National Institute for Health and Clinical Excellence (NICE) in the UK, the Pharmaceutical Benefits Advisory Committee (PBAC) in Australia, and the Pharmaceutical Management Agency (PHARMAC) in NZ.

- Of the 10 drugs deemed least cost-effective by NICE between 1996 and 2005, all were approved for funding in the UK, six were approved in Australia and five were approved in NZ.

- Australia and NZ refused funding for drugs for obesity, influenza and growth deficiency.

- All three countries made exceptions in order to fund drugs of poor cost-effectiveness for some "dread" diseases, but some drugs for less alarming conditions were either not funded or heavily restricted.

MJA 2008; 188: 26-28

... judgements about the acceptability of the technology as an effective use of NHS resources are more likely to make more explicit reference to factors including: the degree of uncertainty surrounding the calculation ...; the innovative nature of the technology; the particular features of the condition and population receiving the technology; where appropriate the wider societal costs and benefits. Above an incremental cost-effectiveness ratio of $£ 30000 /$ QALY, the case for supporting the technology on these factors has to be increasingly strong. ${ }^{7}$

The threshold for cost-effectiveness, albeit with similar qualifications, appears to be lower in Australia (A $\$ 42000, \mathrm{NZ} \$ 49000, £ 18000$ per QALY). ${ }^{4,11}$ No threshold for NZ has been published. Australia and NZ, unlike the UK, employ reference pricing. ${ }^{12,13}$ This means that proposals to fund new drugs are tested ("reference priced") against the relevant therapeutic group of drugs already funded. Proponents of new drugs have to justify any higher price on the basis of superior costeffectiveness. Otherwise, purchasers of these drugs are reimbursed at the price of the cheapest drug in that class. Consequently, price reductions are often negotiated. Discussion of price is explicitly outside NICE's remit. The "budget impact" or total cost (of the drug in the whole population) is an explicit criterion in both Australia and NZ, but not for NICE in the UK, where cost is a matter for the Department of Health. 


\section{Some controversial decisions on funding of pharmaceuticals}

A published review ${ }^{14}$ of the health technologies appraised by NICE in its first 6 years, 1999-2005, identified pharmaceutical products with the worst cost-effectiveness. The list of the top 10 of these drugs is shown in Box 2 .

To check whether these drugs were funded by the public sector in Australia and NZ, respectively, I searched the PBAC and PHARMAC websites. These results were checked with key informants in each authority during a personal visit, and the draft results were confirmed via written comments by the key informants.

The most striking differences were to do with refusals (Box 2). Australia said "no" to four, while the UK said "no" to none. NZ (which funded five) was similar to Australia, except that companies whose drugs were refused funding in Australia tended not to apply for funding in NZ.

Positive decisions to reimburse often came with major restrictions, particularly in Australia and NZ. Almost all the "yes" recommendations in Australia and NZ involved major restrictions relative to licence conditions. ${ }^{14}$ Given NICE's higher cost-effectiveness threshold, this finding was as expected. More surprising was the decision by each country to fund some drugs despite their poor cost-effectiveness.

Interferon beta and glatiramer acetate for multiple sclerosis had the worst cost-effectiveness of the 10 drugs, at $£ 70000$ per QALY (A\$160000, NZ\$191000). All three regulators initially took a strongly negative position, but each country found a way to fund these drugs. In the UK, after NICE turned down funding of interferon beta, the government established a risk-sharing scheme under which prices were reduced, and patients prescribed the drugs were monitored. ${ }^{15}$ In NZ, after PHARMAC recommended against funding, an incoming Labour government honoured an election pledge to extend coverage to these drugs for a specified number of patients. ${ }^{16,17}$ In Australia, interferon beta was eventually recommended by the PBAC under the Section 100 Highly Specialised Drugs Program ${ }^{18}$ after several refusals.

Trastuzumab (Herceptin [Roche]) for advanced breast cancer, with an unfavourable cost per QALY of $£ 38000$ (A $\$ 87000$, NZ\$104000), also posed problems in each country. NICE recommended its use, suggesting that the effectiveness estimate was unduly pessimistic. ${ }^{19}$ In Australia, a separate new program was established in 2001 to provide this drug, after the PBAC rejected it. $^{20,21}$ Similarly, NZ established a separate hospital program to fund cancer drugs, including trastuzumab, for advanced breast cancer. ${ }^{22}$

Imatinib (Glivec [Novartis]) for chronic myeloid leukaemia, priced at around $£ 30000$ per year in the UK, was bound to have relatively poor cost-effectiveness. Despite a cost per QALY of $£ 39000$ (A\$90 000, NZ\$107 000), NICE recommended it for the accelerated phase of the disease. ${ }^{23}$ In Australia, the PBAC recommended it under its Section 100 arrangements. In NZ, PHARMAC initially refused, but funded it after Novartis reduced the prices of a range of its drugs. ${ }^{7,24}$

Tumour necrosis factor- $\alpha$ inhibitors for adult rheumatoid arthritis were accepted in the UK and restricted in Australia and NZ (where only adalimumab was funded). NICE put the cost-effectiveness of each at $£ 31000$ (A $\$ 71000, N Z \$ 85000$ ) per QALY,

\section{Decisions on funding for selected drugs with poor cost-effectiveness, by country (with year of decision)}

\begin{tabular}{|c|c|c|c|c|c|c|c|}
\hline \multirow[b]{2}{*}{ Drug and indication } & \multirow{2}{*}{$\begin{array}{l}\text { Estimate by NICE } \\
\text { Cost/QALY (f) (range) }\end{array}$} & \multicolumn{2}{|c|}{ United Kingdom* } & \multicolumn{2}{|c|}{ Australia $^{\dagger}$} & \multicolumn{2}{|c|}{ New Zealand ${ }^{\dagger}$} \\
\hline & & Decision & Date & Decision & Date & Decision & Date \\
\hline $\begin{array}{l}\text { Interferon beta and glatiramer acetate for } \\
\text { multiple sclerosis }\end{array}$ & 70000 (33000-104000) & Yes $^{\star}$ & 2002 & $\begin{array}{l}\text { Yes, after } \\
\text { several } \\
\text { refusals }\end{array}$ & 1996 & Yes $^{\ddagger \S}$ & 2000 \\
\hline $\begin{array}{l}\text { Antivirals (zanamivir, amantadine or } \\
\text { oseltamivir) for influenza (seasonal prophylaxis } \\
\text { in healthy adults) }\end{array}$ & $54000(8000-100000)$ & Yes $^{\ddagger}$ & 2003 & No & - & No" & - \\
\hline Insulin glargine for type 2 diabetes & $53000(35000-72000)$ & Yes $^{\ddagger}$ & 2002 & Yes $^{\ddagger}$ & 2006 & Yes $^{\ddagger}$ & 2006 \\
\hline $\begin{array}{l}\text { Imatinib for chronic myeloid leukaemia } \\
\text { (accelerated phase) }\end{array}$ & $39000(22000-56000)$ & Yes & 2002 & Yes $^{\ddagger}$ & 2003 & Yes ${ }^{\star \star}$ & 2002 \\
\hline Riluzole for motor neurone disease & 39000 (35 000-44 000) & Yes & 2001 & $\mathrm{Yes}^{\dagger \dagger}$ & 2003 & No" & - \\
\hline Trastuzumab for advanced breast cancer & 38000 & Yes & 2002 & Yes $^{\ddagger}$ & 2002 & Yes $^{\ddagger \ddagger}$ & 2001 \\
\hline $\begin{array}{l}\text { Somatropin for adults with growth-hormone } \\
\text { deficiency }\end{array}$ & 35000 (25 000-45 000) & Yes $^{\ddagger}$ & 2003 & No & 2001 & No§§ & - \\
\hline $\begin{array}{l}\text { Etanercept, infliximab or adalimumab for } \\
\text { adult rheumatoid arthritis }\end{array}$ & 31000 (22 000-35 000) & Yes & 2002 & $\mathrm{Yes}^{\ddagger}$ & 2003 & $\begin{array}{l}\text { Yes } \\
\text { (adalimumab } \\
\text { only) }^{\ddagger}\end{array}$ & 2004 \\
\hline $\begin{array}{l}\text { Infliximab for Crohn's disease } \\
\text { (severe active) }\end{array}$ & 28000 & Yes $^{\ddagger}$ & 2002 & Noףๆ & 2007 & Nol & - \\
\hline Sibutramine for obesity & $23000(15000-30000)$ & Yes $^{\ddagger}$ & 2001 & No & 2006 & No & 2007 \\
\hline \multicolumn{8}{|c|}{ 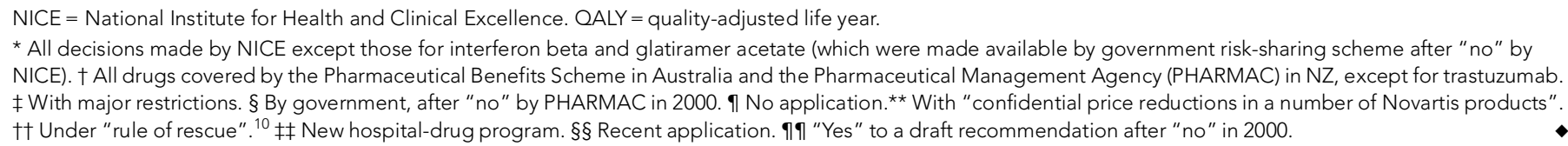 } \\
\hline
\end{tabular}


which, while close to the cost-effectiveness threshold in the UK, was well above that for Australia.

Insulin glargine for type 2 diabetes was funded, with major restrictions, in all three countries. Riluzole for motor neurone disease was funded in the UK and Australia, but no application for funding was made in NZ. Human growth hormone for growthhormone deficiency in adults had major restrictions imposed in the UK and was not funded by the other countries.

\section{What drives pharmaceutical funding decisions?}

Some similarities between the three countries are striking, notably that all three health systems found ways to fund several controversial drugs despite their particularly poor cost-effectiveness. Departures from the normal appraisal process were required to enable funding in several instances, notably for interferon beta in the UK and NZ.

Overall, NICE was more lenient than either Australia or NZ, both of whom differ from the UK in their use of "reference pricing" and concern with the effect on budgets. NZ appears to have been slightly more restrictive than Australia.

Each country found it impossible not to fund several drugs whose cost-effectiveness was poor. Although these decisions may have been justified on the basis of the non-economic criteria used in each country, the normal processes had to be bypassed, notably for interferon beta. Some other drugs were funded under different programs. It is difficult to avoid the conclusion that an important factor in these decisions had to do with the nature of the diseases these drugs treat. When drugs offer the potential to save lives, such as in breast cancer or leukaemia, or alleviate particularly difficult diseases (multiple sclerosis, rheumatoid arthritis), it has proved politically difficult to refuse to fund them. However, the perception of "dread" diseases depends on social factors, such as patient lobbying and public perceptions. Decisions on which drugs to fund, in the final analysis, depend on their political and social acceptability.

\section{Acknowledgements}

Thanks to Andrew Mitchell, who provided information on the Pharmaceutical Benefits Advisory Committee and Rachel Grocott, who provided information on the Pharmaceutical Management Agency. Neither is responsible for the views expressed in this article, which are those of the author alone.

\section{Competing interests}

None identified.

\section{Author details}

James P Raftery, MA, PhD, Director

Wessex Institute for Health Research and Development, University of Southampton, Southampton, UK.

Correspondence: raftery@soton.ac.uk

\section{References}

1 Jacobzone S. Pharmaceutical policies in OECD countries: reconciling social and industrial goals. Labour Market and Social Policy Occasional Papers 40. Paris: OECD, 2000.

2 Hill S, Henry D, Stevens A. The use of evidence in drug selection: the Australian Pharmaceutical Benefits Scheme. In: Moynihan R, editor. Informing judgment: case studies of health policy in six countries. New York: Millbank Memorial Fund and Cochrane Collaboration, 2001.
3 Mitchell AS. Antipodean assessment: activities, actions and achievements. Int J Technol Assess Health Care 2002; 18: 203-212.

4 Taylor RS, Drummond MF, Salkeld G, Sullivan SD. Inclusion of cost effectiveness in licensing requirements of new drugs: the fourth hurdle. BMJ 2004; 329: 972-975.

5 Raftery J. NICE: faster access to modern treatments? Analysis of guidance on health technologies. BMJ 2001; 323: 1300-1303.

6 Metcalfe S, Dougherty S, Brougham M, Moodie P. PHARMAC measures savings elsewhere to the health sector. NZ Med J 2003; 116: U362.

7 National Institute for Health and Clinical Excellence. Guide to the methods of technology appraisal. NO515. London: NICE, 2004. http:// www.nice.org.uk/page.aspx?o=201973 (accessed Oct 2007).

8 Department of Health and Ageing. Guidelines for the pharmaceutical industry on preparation of submissions to the Pharmaceutical Benefits Advisory Committee (PBAC): including major submissions involving economic analyses. Canberra: DHA, 2002. http://www.health.gov.au/ internet/wcms/publishing.nsf/Content/health-pbs-general-pubs-guidelines-index.htm (accessed Oct 2007).

9 PHARMAC (Pharmaceutical Management Agency). PHARMAC decision criteria. http://www.pharmac.govt.nz/pharmaceutical_schedule_ update.asp (accessed Oct 2007).

10 Richardson J, McKie J. The rule of rescue. Working paper 112. Melbourne: Centre for Health Program Evaluation, 2000. http:// www.buseco.monash.edu.au/centres/che/pubs/wp112.pdf (accessed Oct 2007).

11 George B, Harris A, Mitchell A. Cost-effectiveness analysis and the consistency of decision making: evidence from pharmaceutical reimbursement in Australia (1991 to 1996). Pharmacoeconomics 2001; 19: 1103-1109.

12 Danzon PKJD. Reference pricing of pharmaceuticals for Medicare: evidence from Germany, the Netherlands and New Zealand. Cambridge, Mass: National Bureau of Economic Research, 2003.

13 Kanavos P, Rheinhardt U. Reference pricing for drugs: is it compatible with US health care? Health Aff (Millwood) 2003; 22: 16-30.

14 Raftery J. Review of NICE's recommendations, 1999-2005. BMJ 2006; 332: 1266-1268.

15 Department of Health. Cost-effective provision of disease modifying therapies for people with multiple sclerosis. Health Service Circular 2002/ 004. London: Department of Health, 2002. http://www.dh.gov.uk/en/ Publicationsandstatistics/Lettersandcirculars/Healthservicecirculars/DH_ 4004332 (accessed Oct 2007).

16 Masters C. MS patients welcome move to fund drugs. New Zealand Herald 2000; 30 Jun. http://www.nzherald.co.nz/section/1/story.cfm?c_ id=1\&objectid=106706 (accessed Oct 2007).

17 McNaughton H, Kayes N, McPherson K. Interferon beta, PHARMAC, and political directives: in the best interests of people with multiple sclerosis? NZ Med J 2006; 119: U1939.

18 Bailey F. Pharmaceutical Benefits Scheme: betaferon. Question without notice, 10 Sep 1996. Canberra: Australian House of Representatives. http://parlinfoweb.aph.gov.au/ (accessed Oct 2007).

19 National Institute for Health and Clinical Excellence. The clinical effectiveness and cost effectiveness of trastuzumab for breast cancer. Report TA34. London: NICE, 2002. http://guidance.nice.org.uk/TA34 (accessed Oct 2007).

20 Medicare Australia. Trastuzumab (Herceptin). 2007. http://www.medicareaustralia.gov.au/providers/programs_services/herceptin.shtml (accessed Oct 2007).

21 Hall WD, Ward R, Liauw WS, et al. Tailoring access to high cost, genetically targeted drugs. Assessment of real cost effectiveness, with data linked to individual health outcomes while protecting patient privacy, is an essential challenge we need to meet. Med J Aust 2005; 182: 607-608.

22 Ministry of Health. The New Zealand Cancer Control Strategy. Wellington: Ministry of Health, 2003. http://www.moh.govt.nz/moh.nsf/pagesmh/2462? Open (accessed Oct 2007).

23 National Institute for Health and Clinical Excellence. Leukemia (chronic myeloid) -imatinib. Report TA 70. London: NICE, 2002. http://guidance.nice.org.uk/TA70 (accessed Oct 2007).

24 Annual report of Pharmaceutical Management Agency for the year ended 30 June 2003. Wellington: PHARMAC, 2003. http://www.pharmac.govt.nz/pdf/ARep03.pdf (accessed Oct 2007).

(Received 1 Feb 2007, accepted 11 Oct 2007) 